ice dams on rapidly forming rivers or lakes behind dust-hidden glaciers could have burst forth; water could reappear as brief dews or as a build-up of thousands of centuries of light snow. Clathrates may release huge volumes of atmospheric gas, altering conditions for centuries.

The idea of a seasonal Mars comes and goes, itself weirdly seasonal. What is impossible oneyear suddenlybecomeslikelythe next. The ferment of theorizing leads to private and public confusion, but Morton pulls us along with skill and insight through bull session after late-night bull session and conference after conference, keeping the players straight, engaging in light gossip, but clearly explaining the real issues and their ramifications.

The result is one of the best populargeology books I've read, a match for John McPhee's Basin and Range (Farrar Straus Giroux, 1982). To geologists, Mapping Mars will probably function as both a solid lunch and a plate of dessert nibbles, both food and sweets for thought.

Closing the book, science passes into daydream, made vivid by well-drawn scenarios. Mars may indeed be a heaven for geologists. It is the most nakedly fascinating and possibly the most geologically complicated world in our Solar System. Soon, a geologist will go to Mars and pick up a rock, strike it against another rock, and see up close what only human eyes can see. Something surprising, probably impossible.

The fun has justbegun.

Greg Bear has both painted and written about Mars, He is the author of Moving Mars, Darwin's Radio, Vitals and the forthcoming Darwin's Children, and lives in Lynnwood, Washington, USA.

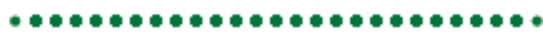
A historian of Victorian astronomy

Agnes Mary Clerke and the Rise of Astrophysios

by Mary Brück

Cambridge University Press: 2002, 286 pp.

$£ 35, \$ 50$

\section{Donald E. Osterbrock}

Agnes Clerke was the most influential writer on astronomy in the English language at the end of the Victorian era. In those days before the Internet, television, radio and even newsreels, people kept abreast of the latest developments in the world by reading books, magazines and newspapers. Astronomy the study of the whole Universe - was as interesting then as it is now. Numerous popularizers churned out repetitious potboilers with such titles as In Starry Realms and Story of the Heavens, but Agnes Clerke wrote solid, well-researched, up-to-date reviews and books for the educated public.

\title{
Lost languages
}

Writing is among the great inventions in human history - perhaps the greatest invention, because it made history possible. The process of deciphering ancient scripts is an intellectual and imagina tive challenge to both archeological scholars and amateurs alike. Each script is unique, so decipherment is akin to invention. These ancient writing systems provide a window to past civilizations, and help us to understand how our modern writing systems function. Andrew Robinson, in his new book Lost Languages (McGraw-Hill, $\$ 34.95$, £25.99), tells the fascinating stories of deciphering Egyptian hieroglyphs, Mayan glyphs and Linear B. He then surveys the important scripts still awaiting decipherment, including the Indus script and the Phaistos disc of

Crete (above), believed to be the world's oldest 'printed' document, dating back to before $1600 \mathrm{BC}$.

Her three most important books, A Popular History of Astronomy in the Nineteenth Century (1885), The System of the Stars (1890) and Problems in Astrophysics (1903), were authoritative surveys of the subject and its history. Probably even more important were the hundreds of articles she wrote, many of them for The Edinburgh Review, a quarterly review actually published in London throughout her lifetime. From 1877 to 1907 , when her last article was printed after her death, Clerke had kept her readers informed and interested in the progress of astronomy and astrophysics.

Mary Brück's book tells the story of this remarkable woman. Agnes Clerke never attended school, nor studied at a university. Born in the small town of Skibbereen in CountyCork, Ireland, she was the daughter of a mixed marriage between a Protestant bank manager and a daughter of a wealthy Roman Catholic family. Agnes was educated at home until the family moved to Dublin in 1861, when she was nineteen. There she continued her studies in the city'slibraries. Sixyears later the family moved to Italy, where they stayed for ten years. Agnes was an excellent linguist, and by the time they all moved to England she was fluent in Italian, French, German and Spanish, as well as Latin and Greek. And she was very wellread, especially in science.

Clerke had already written two articles for The Edinburgh Review from Florence, one describing the rise of the Mafia, and the other on Copernicus in Italy. After moving to London, she soon established herself as a dependable writer with a lively style who could tackle almost any subject in science or classics and produce a well-written article on schedule. She became a contributor to the Encyclopaedia Britannica, which was then being revised, beginning with a long article on Galileo.

Friends were soon urging Clerke to write a history of astronomy, and she realized that she could do it. Astronomywas changingfast at the time, as astrophysics came to the fore. She studied physics and astrophysics on her own, and in four years produced her first book, A Popular History of Astronomy in the Nineteenth Century, which established her as an expert, not only with general readers, but also with astronomers, several of whom reviewed the book very favourably.

She began consulting the researchers themselves to learn their latest results. She had already written to Edward Holden, later the first director of Lick Observatory and himself a prolific writer. He had encouraged her; now all the astronomers she interviewed

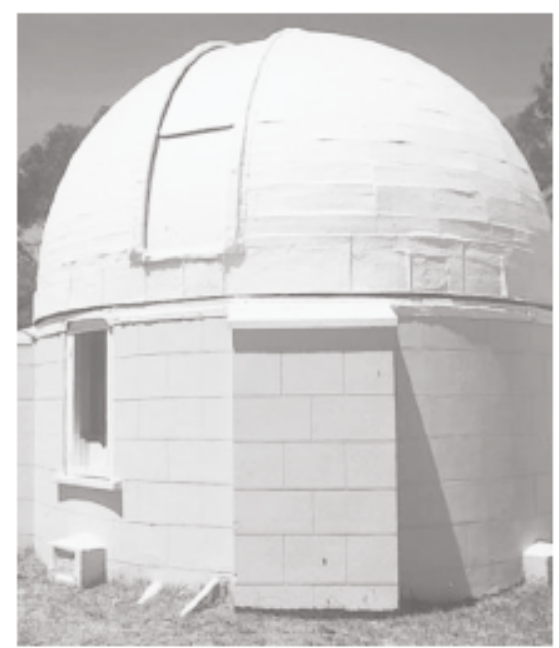

Observation point: Agnes Clerke made her own studies of the stars on a visit to South Africa. 
or wrote to were glad to help, particularly with information about their own discoveries and triumphs. David Gill, a Scottish astronomer who observed the southern skies from South Africa, became a particularly important source for her. In London she met and talked frequently with William Huggins, a pioneer English astrophysicist, and with Norman Lockyer, the founder of Nature. At first she featured their work, but later she came to believe that Huggins was past his prime and that Lockyer claimed more than he actually proved. She paid for that by getting negative reviews of her later books in Nature. Pushy Americans such

as W. W. Campbell and young George Ellery Hale flooded her with their results, and she found some of them important enough to be included in her books.

Clerke also kept up-to-date by attending scientific lectures in London. As a woman she was not permitted to join the Royal Astronomical Society, nor to attend its monthly meetings, but she entered its precincts to use its libraryand to view exhibitions of recent results, especially astronomical photographs. She wrote many articles for the Observatory, the astronomical magazine closely associated with the society, although not owned by it. She was later allowed to come to the society's meetings as a guest of a member, and towards the end of her life she was elected as an honorary member.

Brück has written an excellent book. Her thoroughresearch in numerous archives and in Clerke's publications is well documented in the notes, and numerous well-chosen photographs illustrate the text. There is an extremely informative chapter on women in astronomy in the Victorian era. She concludes, no doubtcorrectly, that a few women could get better jobs inastronomy in America than in Britain, but it seems to me that the difference was only marginal. The case of Alice Everett, a Cambridge graduate, illustrates thiswell. She did good work as an assistant at Greenwich, Potsdam and Vassar College in the United States, but couldn't get a permanent position at any of them. She also applied unsuccessfully to the Lick Observatory, where the director, James E. Keeler, was searching for a male observer at the time.

Brück paints a fascinating picture of the rich fabric of British astronomy and astrophysics at the end of the nineteenth century. This is a highly readable, wellproduced, attractive book. 口

Donald E, Osterbrock is at the Lick Observatory, University of

California, Santa Cruz, California 95064, USA.

\section{A bestial feast}

Dr Tatiana's Sex Advice to All Creation: The Definitive Guide to the Evolutionary Biology of Sex by Olivia Judson

Metropolitan Books/Chatto o Windus: 2002. 320 Pp. $\$ 23 / £ 16,99$

\section{Tim Birkhead}

The first time I went to an international conference and stayed in an expensive hotel, I was amazed by the veritable wall of food that confronted me at breakfast the next morn-

ing. It was an optimalforager's fantasy and I creamed off all the tasty bits from a wide range of dishes. As far as I could tell, everyone else did the same. And that is precisely what Olivia Judson has done, under the guise of agonyaunt Dr Tatiana, on being faced with a surfeit of questions about sex. She's cherrypicked the good bits, flitting from one extramarital relationship to another, without getting bogged down in either a lengthy courtship, a frivolous foreplay or a tedious marriage.

Our understanding of sex is one of the biggest success stories in evolutionary biology. Since the mid 1970s the 'selfish gene' view of biology has completely transformed our view of all aspects of reproduction, from anatomy and physiology to

behaviour, and continues do so as researchers reveal more and more of its remarkable intricacies. Why do male and female birds breed as apparently monogamous pairs yet still engage in extrapair copulations? Why do some flatworms

have a dozen penises when some of us have to make do with one? Why does the female spotted hyena possess a clitoris the size of a courgette, only to have it ripped apart when she gives birth? These are the kind of questions that Dr Tatiana's concerned correspondents ask, albeit rather more directly: "I'm a queen bee, and I'm worried. All my lovers leave their genitals inside me and then drop dead. Is this normal?" Judging from her replies I imagine Dr Tatiana to be some- thing like Dame Edna Everage with a $\mathrm{PhD}$. Nonetheless, as every agony auntshould, Dr Tatiana proffers light-hearted, informative advice. Sex is fun, and fun to read about, especially as in this case it is presented in bite-sized pieces that you can snack on as the fancy takes you. What's on offer spans the entire animalkingdom, from rats to rotifers, and bacteria to birds, and somewhat less digestibly includes some theory too.

The danger, of course, is that presenting research findings as a kind of buffet can trivialize the entire process, turning it into a fast-food fix with none of the benefits of a balanced meal. But Judson walks this particular hedonistic tight-rope with aplomb - her text is both wonderfully entertaining and authoritative - and the inclusion of an extensive section of

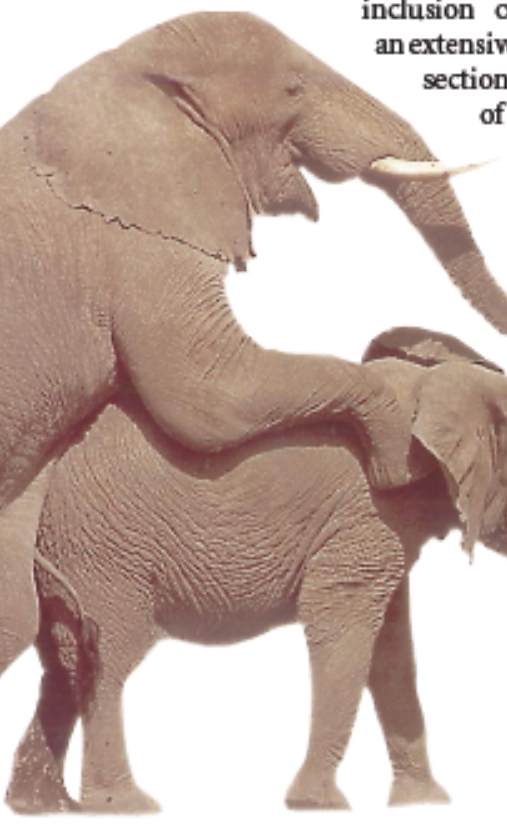

notes and references ensures that she retains her scientific respectability. All in all this is a stimulating feast of extraordinary sexual practices, and my advice is to place $D r$ Tatiana's Sex Advice in the smallest room, where it will keep you entertained and informed for hours.

Tim Birkhead is in the Department of Animal and Plant Sciences, University of Sheffield, Sheffield S1O ZTN, UK, 